\title{
Effect of microalgae Spirulina spp. as food additive on some biological and blood parameters of common carp Cyprinus carpio L.
}

\author{
N.M. Abdulrahman ${ }^{1 *}$, H.J. Hama ${ }^{2}$, Sh.R. Hama ${ }^{2}$, B.R. Hassan ${ }^{1}$ and P.J. Nader ${ }^{3}$ \\ ${ }^{1}$ Department of Animal Sciences, College of Agricultural Sciences, University of Sulaimani, Sulaimani, ${ }^{2}$ Department of \\ Animal Production, University of Raparin, Sulaimani, ${ }^{3}$ Department of Animal Production, College of Agriculture, University \\ of Kirkuk, Kirkuk, Iraq, ${ }^{*}$ email: nasreen.abdulrahman@univsul.edu.iq
}

(Received April 4, 2018; Accepted May 13, 2018)

\begin{abstract}
This study was carried out to study the effect of adding different levels of the microalgae Spirulina spp. in fish laboratory of Animal Sciences Department, College of Agricultural Sciences of Sulaimani University, Sulaimani, Iraq. A total of 72 common carp fingerling weight $45 \pm 2$ gm used to detect the effect of three different levels of the algae Spirulina spp. The control treatment T1 with $0 \%$., T2 with $3 \mathrm{gm} / \mathrm{kg}$ diet and T3 with $5 \mathrm{gm}$ Spirulina $/ \mathrm{kg}$ diet. Each treatment in three replicates in which six fingerlings common carp were stocked in each aquarium. Results indicated no significant differences at $\mathrm{P}<0.05$ in RBC count, gonadosomatic index and hepatosomatic index. Diet T3 $(5 \mathrm{gm} / \mathrm{kg}$ Spirulina $)$ in T3 was higher significantly at $\mathrm{P}<0.05$ in $\mathrm{Hb}$, while control without any Spirulina was higher significantly at $\mathrm{P}<0.05$ in each of platelets, $\mathrm{MCV}, \mathrm{MCH}$ and MCHC. Adding of Spirulina to common carp diets in different levels leads to significant differences in differential WBC counts, T3 with 5 gm Spirulina $/ \mathrm{kg}$ diet was higher in WBC counts. Lymphocytes were higher in each of control and T3. Monocytes were higher in control, granulocytes in T2 with $3 \mathrm{gm}$ Spirulina $/ \mathrm{kg}$ diet. Adding of Spirulina affected significantly in cholesterol as compared to the control. Triglyceride was higher in control and T2. T3 with $5 \mathrm{gm} \mathrm{Spirulina} / \mathrm{kg}$ diet leads to higher and lower significantly in HDL and LDL respectively. T1 and T3 were higher significantly in spleenosomatic index. Inclusion of $S$. platensis in fish diet as a feed additive or as a partial replacer of the expensive fishmeal imposes significant promotions in fish growth, coloration, reproduction and flesh quality.
\end{abstract}

Keywords: Spirulina, Biological parameters, Blood parameters, common carp Available online at http://www.vetmedmosul.com

$$
\begin{aligned}
& \text { تأثير الطحلب الاقيق Spirulina كإضافة غذائية في بعض الصفات البايلوجية والامية لأسماك } \\
& \text { Cyprinus carpio L. الكارب الاعتيادي } \\
& \text { نسرين محي الدين عبدالرحمن'، هاوكار جعفر حمه'، شمال رسول حمه'، باخان رفيق حسن' و بولا جلال نادرّ } \\
& \text { ' قسم علوم الحيوان، كلية العلوم الزراعية، جامعة السليمانية، السليمانية، ` قسم الإنتاج الحيو اني، جامعة رابرين، السليمانية، }
\end{aligned}
$$

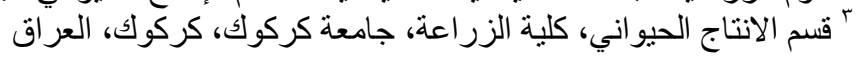

أجريت الدراسة الحالية لبيان تأثير إضافة مستويات مختلفة من الطحلب الدقيق سبيرولينا في مختبر الأسماك لقسم علم الحيوان،

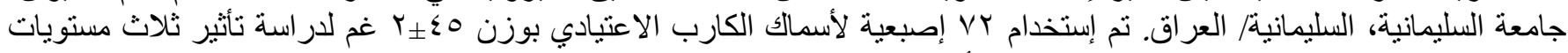

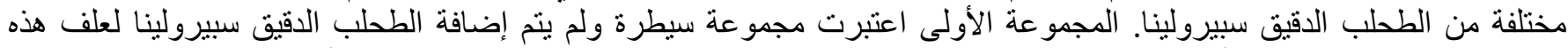

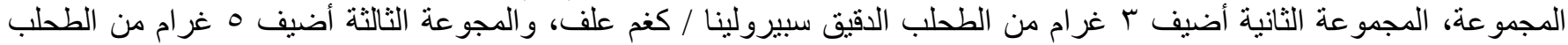

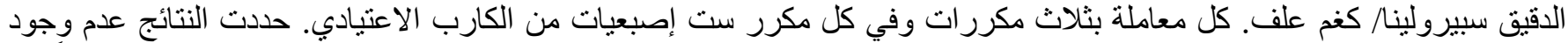

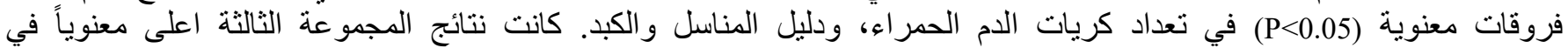




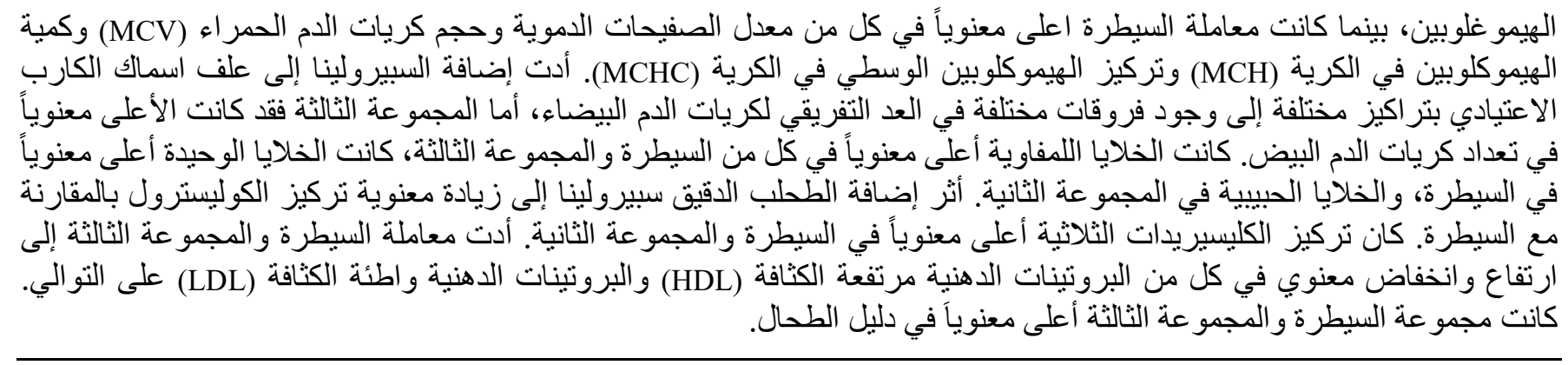

\section{Introduction}

Fisheries have always played a very significant socioeconomic role in many countries and communities, as a subsistence product, fish are a vital resource towards poverty reduction and food security for poorer households (1). Spirulina as "the best for tomorrow", it is gaining popularity in recent years as a food supplement (2). The economic importance of cyanobacteria primarily lies in their agronomic importance as bio fertilizers due to $\mathrm{N}_{2}$ fixation that helps them to grow successfully in habitats where little or no combined $\mathrm{N}$ is available, in recent times, their ability to produce structurally novel and biologically active natural products has been recognized (3-5). Certain cyanobacteria, known as extremophyles, inhabit extreme environments, e.g. Spirulina (alkalophilic), because of their special requirements, mass cultures of extremophyles are likely to be free from microbial contamination thus, avoiding a serious problem in outdoor cultures (6).

Earthrise farms, a commercial producer of Spirulina in California, estimate that Japanese fish farmers used about \$2.5 million worth of Spirulina in 1989 (7). Their promotional literature lists the key benefits associated with the use of Spirulina in aquaculture (a) better growth rates are obtained, and less feed is wasted because of the inherent palatability of Spirulina, fish fed with this cyanobacterium have less abdominal fat, the energy being redirected into growth, this hypothesis was tested and verified in feeding trials with cherry salmon (7), and (b) fish fed Spirulina have an improved quality in terms of flesh flavor, consistency and color. (7) reports that sea bream Acanthopagrus australis, Mackeral Acanthocybium solandri, Yellowtail Seriola lalandi, and ornamental koi carp Cyprinus carpio exhibited enhanced coloration upon feeding with Spirulina supplements. A number of authors (8-10) have investigated the utilization of microalgae in the diet of aquaculture species. Phytobiotic are beneficial for modulation the growth performance and non-specific immunity of fish, based on the study of (11) the phytobiotic mixture composed of garlic and Spirulina is recommended as a potential nutraceutical and immunostimulant feed additives in cultured tilapia.
The aim of present study was to examine the effects of adding Spirulina to diet on some biological and blood parameters of Cyprinus carpio.

\section{Material and methods}

\section{Experimental fish}

The experiment was conducted for 42 days and for this purpose 72 fingerlings common carp C. carpio L. (weights ranged between 40-49 gm) were brought Daquq/ Kirkuk/ Iraq. The fish were sorted depending on size then weighed and put in experimental plastic tank. The fish were acclimated to laboratory conditions and fed with control pellets ( $31 \%$ protein) prior to the feeding trials for 21 days.

\section{Experimental system and design}

Twelve plastic tanks $(100 \mathrm{~L})$ were used in this trial. Each tank was provided with a proper continuous aeration. Each tank was stocked with six fish. The numbers of treatments in the trial were three with three replicates for each. The tanks (replicates) were randomly allocated to minimize differences among treatments. The continuous water flow discharged non-consumed feed and feces particles from the aquaria. In addition, a daily cleaning by siphon method was applied to remove remaining particles from the system.

\section{Diet formulation}

Experimental diets were prepared with the ingredients shown in table 1 . The ingredients were mixed with water to obtain dough. Then, the dough was passed through an electrical mincer for pelleting by using Kenwood Multiprocessors. The pellets were dried at room temperature for a few days and crushed to yield fine particles. Feeding rate was determined to be $3 \%$ of body weight, fish were individually weighed weekly. The feeding amount was then recalculated according to weekly weights.

\section{Used Spirulina}

Blue green algae tablets as food additives, the product information as labelled per three tablets contain $1500 \mathrm{mg}$, their ingredients are D-Calcium phosphate, microcrystalline cellulose, Anticaking agents (Silicon Dioxide, vegetable 
sources Magnesium Stearate). Manufactures in the UK to GMP and pharmaceutical standards, Natures Aid Ltd. Preston PR4 2DQ UK.

Table 1: The Ingredients of experimental diet

\begin{tabular}{lc}
\hline Ingredients & Weight in diet $(\mathrm{gm} / \mathrm{kg})$ \\
\hline Fishmeal & 150 \\
Soybean & 350 \\
Wheat bran & 130 \\
Wheat flour & 100 \\
Barely Meal & 100 \\
Corn Meal & 100 \\
Starch & 50 \\
Minerals premix & 20 \\
\hline
\end{tabular}

\section{Studied traits}

Blood was obtained by cutting the caudal peduncle of every fish to use for blood indices and some blood biochemical by using the hematology analyzer BC-2800 which is a compact, fully automatic hematology analyzer with 18 parameters for Complete Blood Count (CBC) test that calibrated for fish blood as the following:

RBC (Red Blood Cell; $10^{12}$ cells/l), Hb (Hemoglobin; $\mathrm{g} / \mathrm{l})$, platelets $\left(10^{9}\right.$ cells/l), MCV (Mean Corpuscular Volume; fl), $\mathrm{MCH}$ (Mean Corpuscular Hemoglobin; pg), MCHC (Mean Corpuscular Hemoglobin Concentration; $\mathrm{g} / \mathrm{l})$, WBC (White Blood Cell; $10^{9}$ cells/l), lymphocytes (\%), monocytes (\%), granulocytes (\%), glucose, total blood protein, lipid profiles (including cholesterol, triglyceride,
HDL (High Density Lipoproteins) and LDL (Low Density Lipoproteins).

After dissection liver, gonad and spleen weighted separately to obtain the below traits by using the equation according to (12):

Hepatosomatic index $\%=$ liver weight $(\mathrm{g}) /$ body weight $(\mathrm{g})$ $\mathrm{x} 100$

Gonadosomatic index (GSI) \% = Gonads weight (g)/ Body weight $(\mathrm{g}) \times 100$

Spleenosomatic index=Spleen weight/body weight (g)x 100

\section{Statistical analysis}

Analysis of variance was conducted by using the general linear models (GLM) procedure of XLSTAT. Pro. 7.5 One way (ANOVA). Fisher's LSD tests was used to compare between means of the control and experiment treatments.

\section{Results and discussion}

Table 2 show no significant differences in RBC count, 5 gm Spirulina $/ \mathrm{kg}$ diet in T3 was higher significantly in $\mathrm{Hb}$, control without any Spirulina was higher significantly in each of Platelets, MCV, $\mathrm{MCH}$ and $\mathrm{MCHC}$.

Adding of Spirulina to common carp diets in different levels leads to significant $(\mathrm{P}<0.05)$ differences in studied differential WBC counts, T3 with $5 \mathrm{gm}$ Spirulina $/ \mathrm{kg}$ diet was higher in WBC counts. Lymphocytes were higher in each of control and T3. Monocytes were higher in control, Granulocytes in T2 with $3 \mathrm{gm}$ Spirulina $/ \mathrm{kg}$ diet, as shown in table 3.

Table 2: Effect of adding different levels of Spirulina on some blood indices of common carp Cyprinus carpio L.

\begin{tabular}{lccccccc}
\hline Treatments & RBC & Hb & PLT & HCT & MCV & MCH & MCHC \\
\hline \multirow{2}{*}{ T1: 0 Spirulina } & 1.482 & 9.600 & 67.000 & 35.720 & 227.700 & 66.775 & 30.300 \\
& $\mathrm{~A}$ & $\mathrm{~B}$ & $\mathrm{~A}$ & $\mathrm{~B}$ & $\mathrm{~A}$ & $\mathrm{~A}$ & $\mathrm{~A}$ \\
T2: 3 gm Spirulina $/ \mathrm{kg}$ diet & 1.465 & 7.925 & 28.667 & 29.975 & 197.367 & $59.625 \mathrm{AB}$ & 29.167 \\
& $\mathrm{~A}$ & $\mathrm{C}$ & $\mathrm{C}$ & $\mathrm{C}$ & $\mathrm{B}$ & $\mathrm{AB}$ \\
T3: 5 gm Spirulina $/ \mathrm{kg}$ diet & 1.796 & 10.700 & 38.000 & 37.200 & 208.567 & 58.975 & 27.167 \\
& $\mathrm{~A}$ & $\mathrm{~A}$ & $\mathrm{~B}$ & $\mathrm{~B}$ & $\mathrm{AB}$ & $\mathrm{AB}$ & $\mathrm{BC}$ \\
\hline
\end{tabular}

Mean values with different superscripts within a column differ significantly at $\mathrm{P} \leq 0.05$.

Table 3: Effect of adding different levels of Spirulina on WBC differential count of common carp Cyprinus carpio L.

\begin{tabular}{lcccc}
\hline Treatments & WBC & lymphocytes & monocytes & granulocytes \\
\hline \multirow{2}{*}{ T1: 0 Spirulina } & 155.850 & 7.150 & 34.900 & 57.950 \\
& $\mathrm{~B}$ & $\mathrm{~A}$ & $\mathrm{~A}$ & $\mathrm{~B}$ \\
T2: 3 gm Spirulina $/ \mathrm{kg}$ diet & 141.967 & 4.733 & 30.233 & 65.033 \\
& $\mathrm{C}$ & $\mathrm{B}$ & $\mathrm{C}$ & $\mathrm{A}$ \\
T3: 5 gm Spirulina $/ \mathrm{kg}$ diet & 161.567 & 6.900 & 32.200 & 60.900 \\
\hline
\end{tabular}

Mean values with different superscripts within a column differ significantly at $\mathrm{P} \leq 0.05$. 
No significant $(\mathrm{P}>0.05)$ differences observed in blood glucose among the treatments, total protein was higher significantly in control and T3 with $5 \mathrm{gm}$ Spirulina $/ \mathrm{kg}$ diet.

Adding of Spirulina affected significantly in cholesterol as compared to the control. Triglyceride was higher in control and T2. T3 with $5 \mathrm{gm}$ Spirulina $/ \mathrm{kg}$ diet leads to higher and lower significant in HDL and LDL respectively, as shown in table 4 .
(13) found significant differences of Spirulina on blood parameters of Nile Tilapia fingerlings (Oreochromis niloticus). The supplementation of Spirulina sp. resulted in no changes of blood parameters or histology of catfish, Clariasmacro cephalus x Clarias gariepinus in the study of (14).

Table 4: Effect of adding different levels of Spirulina on some blood biochemical of common carp Cyprinus carpio L.

\begin{tabular}{lcccccc}
\hline Treatments & glucose & total protein & cholesterol & triglyceride & HDL & LDL \\
\hline T1: 0 Spirulina & 1.735 & 38.045 & 2.965 & 2.600 & 1.175 & 1.270 \\
& $\mathrm{~A}$ & $\mathrm{AB}$ & $\mathrm{B}$ & $\mathrm{A}$ & $\mathrm{C}$ & $\mathrm{A}$ \\
T2: $3 \mathrm{gm}$ Spirulina $/ \mathrm{kg}$ diet & 2.040 & 36.160 & 3.385 & 2.597 & 1.797 & 1.070 \\
& $\mathrm{~A}$ & $\mathrm{~B}$ & $\mathrm{~A}$ & $\mathrm{~A}$ & $\mathrm{~B}$ & $\mathrm{~A}$ \\
T3: $5 \mathrm{gm}$ Spirulina $/ \mathrm{kg}$ diet & 2.147 & 38.687 & 3.250 & 1.900 & 3.560 & 0.377 \\
& $\mathrm{~A}$ & $\mathrm{~A}$ & $\mathrm{~A}$ & $\mathrm{~B}$ & $\mathrm{~A}$ & $\mathrm{~B}$ \\
\hline
\end{tabular}

Mean values with different superscripts within a column differ significantly at $\mathrm{P} \leq 0.05$.

According to the results of (15) dietary supplementation of $3.4 \%$ Spirulina may enhance innate immunity of olive flounder Paralichthys olivaceus. They examined the effects of Spirulina on serum cholesterol and triglyceride levels, as well as AST and ALT levels, and found significant reductions in cholesterol and triglyceride levels. However, although the levels of AST and ALT were decreased by Spirulina supplementation, no significant differences were observed among treatments.

Fish mostly rely on innate immunity in comparison to mammals (16). Accordingly, great attention has been focused on the use of dietary bioactive materials to stimulate innate immunity. The immunomodulatory activity of Spirulina has been attributed to its content of Cphycocyanin (17).

A significant difference found in the study of (18) which was conducted to evaluate the effect of replacing fishmeal with Spirulina spp. on carcass composition. (8) fed the fish 5\% algae had insignificant $(\mathrm{P}>0.05)$ increase in total proteins. These findings confirm those reported that the muscle protein of red sea bream was increased as Ascophyllum meal supplementation increased, the role of algae on fat content are in full agreement with the finding reported that 5\% dietary Ascophyllum meal had insignificant increase in muscle fat of red sea bream.

As afore mentioned, overall a lot of factors e.g. levels of Spirulina, production system, physiological status and endogenous factors such as nutritional status and composition involved in inconsistent of our results with the other previous reports in fish. Thus, it seems possible to use of Spirulina as a protein source in aquaculture industry.

Table 5 showed no significant differences in each of gonadosomatic index and hepatosomatic index, T1 and T3 were higher significantly in spleenosomatic index.

Table 5: Effect of adding different levels of Spirulina on some biological parameters of common carp Cyprinus carpio L.

\begin{tabular}{lccc}
\hline Treatments & Gonadosomatic Index & Hepatosomatic Index & Spleenosomatic Index \\
\hline T1: 0 Spirulina & 0.774 & 1.691 & 0.113 \\
& $\mathrm{~A}$ & $\mathrm{~A}$ & $\mathrm{AB}$ \\
$\mathrm{T} 2:$ gm Spirulina $/ \mathrm{kg}$ diet & 0.568 & 2.168 & 0.068 \\
& $\mathrm{~A}$ & $\mathrm{~A}$ & $\mathrm{~B}$ \\
$\mathrm{~T} 3: 5 \mathrm{gm}$ Spirulina $/ \mathrm{kg}$ diet & 0.846 & 1.711 & 0.119 \\
& $\mathrm{~A}$ & $\mathrm{~A}$ & $\mathrm{~A}$
\end{tabular}

Mean values with different superscripts within a column differ significantly at $\mathrm{P} \leq 0.05$.

The present results agree with the results of (19) which were designed to investigate the effect of different replacement levels of fishmeal with Spirulina sp. on growth performance and some blood parameters of common carp Cyprinus carpio L., no differences observed among the treatments in the hepatosomatic and gonadosomatic index 
and this disagree with the present results. Biochemical analyses often provide vital information for health assessment and management of cultured fish $(20,21)$.

The results indicated that Spirulina can be a good choice as an additive for fish diets. Due to supreme level of blood indices involved in fish immunity. The findings of (22) revealed that the dietary addition of microalgae Chlorella could increase the immune response. It is noteworthy to say that studies concerning dietary inclusion of C. vulgaris as a functional ingredient or as an immunostimulant in koi fish are limited. Furthermore, the Spirulina could decrease the level of blood cholesterol, not the glucose of common carp, demonstrating that the Spirulina might be involved in the metabolism of lipid. The same results were also found by (22) and (23).

Inclusion of $S$. platensis in fish diet as a feed additive or as a partial replacer of the expensive fishmeal imposes significant promotions in fish growth, coloration, reproduction and flesh quality.

\section{References}

1. FAO. The state of world fisheries and aquaculture. FAO Fisheries and Aquaculture. Department Food and Agriculture Organization of the United Nations Rome; 2010. 93p.

2. Hasan MR, Chakrabarti R. Use of algae and aquatic macrophytes as feed in small-scale Aquatic: a review. FAO Fisheries and Aquaculture. Department Food and Agriculture Organization of the United Nations Rome; 2009. 135p.

3. Sielaff $H$, Christiansen $G$, Schwecke T. Natural products from cyanobacteria: exploiting a new source for drug discovery. IDrug. 2008;9:119-127.

4. Sahu D, Priyadarshani I, Rath B. Cyanobacteria: as potential biofertilizer. CIBTech J Microbiol. 2012;1(2-3):20-26.

5. Tan LT. Filamentous tropical marine cyanobacteria: a rich source of natural products for anticancer drug discovery. J Appl Phycol. 2010;22(5):659-676.

6. Al-Badri SHA. Effect of environmental factors and some pollutants on the chemical content and nutritional value of blue-green alga Spirulina platensis (Nordst) Geilter. [master's thesis]. Thi-Qar: University of Thi-Qar; 2010. 187p.

7. Henson R. Spirulina improves Japanese fish feeds. Aquatic Mag. 1990;6:38-43.

8. Allam HY. Physiological effects of some additives on growth, blood, constitutes and immunity in Nile tilapia (Oreochromis niloticus) [master's thesis]. Assiut: University of Assiut; 2007. 99p.

9. Ayoola AA. Replacement of fishmeal with alternative protein source in aquatic [master's thesis]. North Carolina (NC): North Carolina State University; 2010. 145p.
10. Al-Koye HJ. Effect of Using Spirulina spp. instead of fishmeal on growth, blood picture and microbial load of common carp Cyprinus carpio [master's thesis]. Erbil: University of Salahuddin; 2013. 131p.

11. Abu-Elala NM, Galal MK, Abd-Elsalam RM, Mohey-Elsaeed O, Ragaa NM. Effects of dietary supplementation of Spirulina platensisand garlic on the growth performance and expression levels of immune-related genes in Nile tilapia (Oreochromis niloticus). J Aquac Res Develop. 2016;7:433.

12. Lagler KF. Fresh water fishery biology. $1^{\text {st }}$ ed. Dubuque: WC Brown Company; 1956. 131-135.

13. Zeinab AK, Aly MS, Faiza AK, Fatma EM. Effect of Spirulina platensis and Lactobacillus rhamnosus on growth and biochemical performance of Nile tilapia (Oreochromis niloticus) fingerlings. Int J Curr Microbiol App Sci. 2015;4(4):747-763.

14. Phromkunthong W, Pipattanawattanakul A. Effects of Spirulina sp. on growth performance and antibody levels in hybrid catfish, Clarias macrocephalus x Clarias gariepinus (Burchell). Songklanakarin J Sci Technol. 2005;27(1):115-132.

15. Kim S, Rahimnejad S, Kim K, Lee B, Lee K. Effects of dietary supplementation of spirulina and quercet in on growth, innate immune responses, disease resistance against Edwardsiella tarda, and dietary antioxidant capacity in the juvenile olive flounder Paralichthys olivaceus. Fish Aqua Sci. 2013;16(1):1-8.

16. Swain P, Dash S, Sahoo PK, Routray P, Sahoo SK, Gupta SD, Meher PK, Sarangi N. Non-specific immune parameters of brood Indian major carp Labeorohita and their seasonal variations. Fish Shellfish Immunol. 2007;22:38-43.

17. Venkataraman LV. Spirulina platensis (Arthospira): physiology, cell biology and biotechnology. J Appl Phycol. 1997;9:295-296.

18. Abdulrahman NM. Effect of replacing fishmeal with Spirulina spp. on carcass chemical composition of common carp Cyprinus carpio L. Iraqi J Vet Sci. 2014;28(2):67-70.

19. Abdulrahman NM, Hamad HJ. Effect of Replacing Fishmeal with Spirulina sp. on some biological parameters of common carp Cyprinus carpio L. Bas J Agric Sci. 2013;26(special issue 2):246-251.

20. Cnaani A, Tinman S, Avidar Y, Ron M, Hulata G. Comparative study of biochemical parameters in response to stress in Oreochromis aureus, O. mossambicus and two strains of $O$. niloticus. Aquatic Res. 2004;35:1434-1440.

21. Řehulka J, Minařík B, Řehulková E. Red blood cell indices of rainbow trout Oncorhynchus mykiss (Walbaum) in aquaculture. Aquacult Res. 2004;35(6):529-546.

22. Khani M, Soltani M, Shamsaie Mehrjan M, Foroudi F, Ghaeni M. The effects of Chlorella vulgaris supplementation on growth performance, blood characteristics, and digestive enzymes in Koi (Cyprinus carpio). Iran J Fish Sci. 2017;16(2):832-843.

23. Güroy D, Güroy B, Merrifield DL, Ergün S, Tekinay AA, Yiğit M. Effect of dietary Ulva and Spirulina on weight loss and body composition of rainbow trout, Oncorhynchus mykiss (Walbaum) during a starvation period. J Anim Physiol Anim Nut. 2011;95:320327. 